\title{
Peace Education through Digital Literacy on Social Media (Analysis of the ability of facilitators in Poso District Women's School of Peace) YTB Tacoh \\ Universitas Kristen Satya Wacana, Salatiga \\ yuliana.tacoh@uksw.edu; yuliana.tacoh@staff.uksw.edu
}

\begin{abstract}
Peace building in post-conflict areas especially in Poso Regency can be developed through Peace Education activities. Peace Education can be done by educating the public through the use of information media that are now rife with digital media or social media. This research focuses on digital literacy of women. The purpose of this study was to determine the ability of digital media literacy of the Women's School Facilitators to utilize Facebook social media in the context of developing peace education activities to educate the public about the importance of peace building. Research This is a research Qualitative descriptive, the study subjects were five facilitators of school girls, from some of the School of Women in Poso district. Data collection techniques in this study were structured interviews. The results of the study showed that the literacy ability of digital media facilitators of the Women's School by using the criteria in the Individual Competence Framework can be said for the first point of personal competence, namely technical skills are good. While the critical understanding point is still not enough or limited. Likewise for Communicative Abilities, the ability of facilitators is still limited. This shows that the ability of women school facilitators in using social media Facebook and being able to see the news of peace building can be said to be good. The ability of women school facilitators to utilize social media in sharing peace content still needs to be improved.
\end{abstract}

Keywords: Digital Literacy, Peace Education, Women's Schools

\section{INTRODUCTION}

Peace education is the main material in learning activities in women's schools in Poso Regency [1] . The learning achievement of this activity is when participants can take part in voicing justice and peace building in various community activities for the sake of building peace among families and communities. To do all of that , of course, by utilizing various means of communication to connect with the community and other communities. If this role can be carried out, participants will spread the spirit of peace building and educate the public about the importance of peace building. Spread the spirit of mem building peace now more easily done by utilizing the means - the means of communication such as digital social media. But how social media is used efficiently certainly requires a literacy ability from the participants of this school to be able to be present in the community as an agent of peace.

In the current digital era, people have used social media to be a part of communication and interaction activities. This can be seen from the research results of the media company We Are Social in collaboration with Hootsuite, that there are 150 million users of social media 
users in Indonesia. That number rose 20 million users compared to the results of research in 2018. Still the same as last year, Facebook became the most popular social media application in Indonesia, with 81 percent penetration. Facebook users were detected as male users by 56 percent, while 44 percent were female . [2] Research from Priliantini and Damayanti (2018 [3] on the Role of Facebook Social Media in forming group solidarity in the 411 and 212 actions, departing from the phenomenon that group solidarity was formed from social media. Social media is considered capable of disseminating information massively and realtime to all his followers Facebook is a social media that is the main reference, although the results of his research show that the activities on Facebook of the people who lead Action 411 and 212 do not influence the formation of solidarity in the action participants, but social media what is more private is Whatsapp, but this has shown that social media has become a means of communication and information that makes it easy for individuals to interact and can even influence each other to spread information and opinions, and social media can also be a means to educate the wider community about peace. A result research by Carmichael Norvang (2014) [4] entitled A Global Dialogue on Peace: Creating an International Learning Community Through Social Media shows that building a dialogue about peace that is carried out through social media, as the creation of an international learning community. This means that learning communities for peace dialogue can occur between countries through social media.

Women's school activities that refer to peace education, can be seen on a facilitator's Facebook social media account . From a number of facilitators in the new women's school, several people are actively using social media to publish information about learning activities in women's schools. The extent to which social media is used as a means of communication and information by the School of Women to develop peace education learning? This is very much related to the ability of individuals in digital media literacy.

Research result of Mulawarman, Aldila Dyas Nurfitri on User Behavior Social Media and its Implications Seen from Perspective Social Psychology Applied [5] ] analyze several issues, browse the latest related to the use of social media is relatively seize the attention of academics and researchers, namely Selfie (selfie), cyberwar, online shopping, user personalization, and share culture. This means that there is still more use of social media in that direction. If so, it can be said that the consequences of the use of social media, and how to use them productively are not yet understood. In his research on digital literacy maps in Indonesia, Novi Kurnia and Santi Indra Astuti (2017) [6] also said that the wide range of issues such as information hoaks, violation of privacy, cyberbullying, violent content and pornography, and addiction digital media is considered as a community issue latest digital. This study also departs from the question whether the problem arises because of the low digital literacy in Indonesia?

In his article titled Building the Nation Character through Digital Literacy, Dyna Herlina S [7] says that some of the above phenomenon shows that Internet users in Indonesia is actually still stutter face of this media. On the one hand they can access the network, operate hardware and apply digital media software but users do not fully understand the consequences of using digital media. What's more, many users have not used it to obtain, disseminate and supply information that is true and beneficial for life together . Individual ability to use media is very dependent on digital media literacy.

This study wants to examine the ability of digital media literacy of the Women's School Facilitators to utilize social media facebook in the context of developing peace education activities. Why focus on the competency of the facilitator? Facilitators are professionals in educational institutions that have the task of planning, implementing, 
evaluating and following up on educational programs that are carried out [8]. Because by knowing the competency of the facilitator, it is expected that further research will be a recommendation on further peace education materials on digital media literacy education to all participants Women School. So peace education is not only discussed in class but can also reach the wider community. Because the use of social media can not be avoided anymore in this digital era. Social media can be used to disseminate and even to become a medium for peace education. The purpose of this paper is to determine the literacy ability of the Women's School facilitator digital media in developing peace education through Facebook social media.

In addition to the studies previously stated about the role of social media building solidarity [3] and international dialogue internationally about peace through social media [4] Research related to the use of Facebook and media literacy has been carried out by Mutaqqien, [9] which focuses on describing the ability media literacy among rural adolescents in Lamongan Regency. It can be said that this research has taken a different focus from previous research so that it is expected to be able to add to the treasury of science, especially media studies

This research is important given that the perspective of adult woman's social media users has not been conducted even though facebook social media users detected by women are quite large in Indonesia and the results of research for facebook users age have a high penetration in adulthood in the range 25-44 year [2]. Study of adult women about how they can be skilled in social media literacy for peace, of course it is hoped that later they will also be able to educate their own families and subsequently the community.

The peace education curriculum developed at the women's school is a "Women's Friendly" peace education model [1]. Departing from the understanding of peace education is a process of planned and systematic educational activities to directly instill, support, show and influence the development of knowledge, thoughts, feelings, skills, values, and attitudes needed to promote peace. The aim is to help individuals and society gain relevant knowledge and skills, personal values and behaviors to apply commitment and strive actively and independently for a peaceful life in all aspects of life.

The definition of peace education used according to circumstances and places, refers to a philosophy that teaches non-violence, love, compassion, trust, justice and cooperation and respect for the human family and all life on this Planet. From that philosophy, peace education must produce an ability or skill that includes communication, listening, understanding different perspectives, cooperation, problem solving, critical thinking, decision making, conflict resolution, and social responsibility for participants [1].

Departing from this understanding, the learning in the Women's School aims to make the female school participants become independent in peace building in the community. This ability is also expected to be seen through the use of various means of communication including social media to develop peace education that reaches the wider community, called Digital Social Media Literacy Capability. The term social media is interpreted from the word "media" that is as a means of communication, and the word "social" which is interpreted as a social reality where each individual takes action that contributes to society. More explicitly that "media" as a communication tool is a product of social processes, and by users used in social processes [5]

Social media can be an effective means of communication for clicking eloped peace education. Kompas cites McQuail (2016) as saying the advantages of using internet, including social media, namely, There is a two-way communication in equality, time and cost efficiency, 
fast and knows no geographical boundaries. Developing peace education can take advantage of the convenience offered by social media, namely the presence of airy space, open-plan, and full equality for constructive dialogue. This is a new way of social interaction, and humans are formed in it. Mass communication shape the way humans develop cognitive, cultural and social, facilitates the human desire to share the information and communicate in social networks and allow for dialogue about the perspective of the value [15] .

Digital literacy is related to some basic literacy abilities, or a combination of several forms of literacy, namely: computers, information, technology, visuals, media and communication. then Martin (2008, in Bekti et al 2019) formulated the following dimensions of digital literacy: (1) Digital literacy involves the ability of digital action which is bound by work, learning, pleasure and other aspects of daily life. (2) Individual digital literacy varies depending on the daily situation he experiences and also lifelong processes as the individual's life situation. ( 3 ) Digital literacy is formed by but broader than information communication technology literacy. (4) Digital literacy involves the ability to collect and use knowledge, techniques, attitudes and personal qualities as well as the ability to plan, carry out and evaluate digital actions as part of solving problems / tasks in life. ( 5 ) Digital literacy also involves one's awareness of the level of digital literacy and the development of digital literacy [10] . Literations are tiered digital as disclosed by Mayes and Fowler (2006). The following figure shows the tracking .

PICTURE 1. Digital Literacy Level

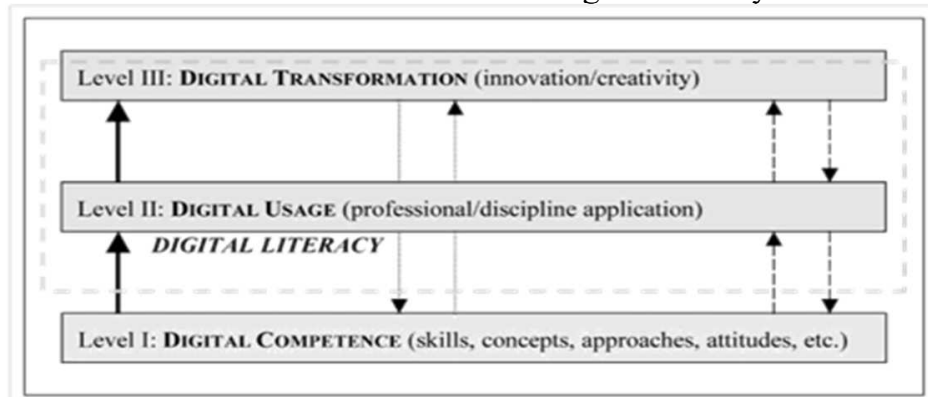

Sources: Lankshear and Knobel 2008, 167

At the first level of digital literacy, digital competence, one must master the basic abilities, concepts, approaches and actions when dealing with digital media. At the second level of digital use, one can apply applications for productive/professional purposes, for example using digital media for business, teaching, social campaigns, etc. Whereas at the top level, digital transformation, a person is able to use digital media to innovate and creativity for the wider community. [11]

The Women's School Facilitator's media literacy capabilities will use criteria using the Individual Competence Framework in the 2009 Final Report Study on Criteria for Media Literacy Levels [12] conducted by the European Commission. Individual Competence is a person's ability to use and utilize media. Among these are the ability to use, produce, analyze and communicate messages through the media. These individual competencies fall into two categories:

(1) Personal competence, i.e. one's ability to use media and analyze media content. Personal competence consists of two criteria, namely: a. Technical skills, namely the technical ability to use media. That is, someone is able to operate the media and understand all types of instructions contained therein. Technical skills include several criteria, namely: (1) Ability to use computers and the internet (2) Ability to use media actively (3) Ability to use the internet 
high b. Critical understanding, namely cognitive abilities in using media such as the ability to understand, analyze and evaluate media content. The criteria include: (1) Ability to understand media content and functions (2) Having knowledge of media and media regulation (3) User behavior in using media

(2) Social competence, which is a person's ability to communicate and build social relations through the media and be able to produce media content. This social competence consists of Communicative Abilities, namely the ability of communication and participation through the media. Communicative abilities include the ability to build social relations and participate in the community through media. Besides this communicative abilities also include the ability to create and produce media content measuring the level of media literacy abilities. Communicative abilities include several criteria, namely: (1) The ability to communicate and build social relations through media. (2) Ability to participate with the public through media (3) Ability to produce and create media content

\section{RESEARCH METHOD}

This research method is a descriptive format research. This study uses structured interviews as a data collection technique or research instrument. The questions on interview list are based on the indicators in the Individual Competence Framework [12] . Respondents in this study are in addition to the Women's School Facilitator and Chairperson of the Women's School Presidium. Facilitators are the teaching staff and who coordinate women's school activities. Chairman of the presidium of 15 Girls' School leaders in Poso district. Data Analysis Technique This research is descriptive qualitative.

\section{RESULTS AND DISCUSSION}

The following is a presentation of the results of this study through the indicators contained in the Individual Competence Framework which is divided into two parts, namely personal competence and social competence.

Personal competence, i.e. one's ability to use media and analyze media content. Personal competence can be seen from two criteria, the first is technical skills, namely the technical ability to use media. This means that someone is able to operate the media and understand all types of instructions contained in it, which can be seen from the ability to use computers and the internet, the ability to use social media actively and use the internet high. In this technical skills point, the written interview results show that the ability of facilitators in the Women's School for the field of technical skills is already visible . For Capacity of respondents to operate and use the Internet and media social facebook largely demonstrated the ability to view the activity of those who upload a facebook account past peacekeeping educational activities. Respondents also stated the ability to see the message of peace and the development of peace reporting to develop peace education from the status of other users as well as advertising content. Of the four facilitators, three said that they often used social media to share information about the news of peace. They also sometimes use Facebook to see the entertainment side. The overall results of the survey show that the facilitators already have a good ability to operate the media and use social media actively.

The second point in personal competence is critical understanding, namely the cognitive ability to use media as well as the ability to understand, analyze and evaluate media content. On the criteria of being able to understand the content and function of the media the facilitators said they did not really understand. On the criteria of having knowledge about the 
media and media regulation and user behavior in using media, the answers of the facilitators also varied, some answered knowing even though some also stated no. On the criteria of the ability to understand the news and language of peace, understanding the peace reporting, the facilitators answered that they have the ability, but the ability to understand the background that makes the news not yet owned. On the ability to understand Facebook's social media usage regulations, the facilitators stated that they knew enough even though they did not really understand. Criteria for the ability to criticize the news on Facebook that does not contain the message of peace is done only occasionally. The ability to discuss peace messages from Facebook with others is often done. The ability to advise others to follow any peace status on Facebook has often been done. The ability to close Facebook when viewing news that opposes peace is not often done. The ability to link the preaching of peace on Facebook with life experience is also often done. The ability to criticize the way of preaching peace, advertising that is not in accordance with peace is quite often done. However, comparing the reporting of peace on other social media the number of Facebook friends uploaded about peace is not often done. For the ability to feel satisfied when seeing news or peace status on Facebook, all facilitators responded that they were always satisfied. In general it can be said criteria is that the cognitive ability in using the media and to understand, analyze $\mathrm{s}$ and evaluate media content, the ability of the facilitators is limited.

The second criterion in the Individual Competence Framework is social competence, one's ability to communicate and build social relations through the media and be able to produce media content. This social competence consists of communicative abilities, namely the ability to communicate and participate through the media, especially the internet. Communicative abilities include several criteria, namely the ability to communicate and build social relations through media, and the ability to produce and create media content. In this criterion, the ability to be seen is to be able to reconcile peace with others in any form, for this ability the respondent answered that he is quite capable. While the ability to use social media facebook to monitor the development of the peace situation, and share information and messages of peace, quite often do it. But making funny messages (memes) facilitators don't often do it. The ability to criticize an unsafe situation is not often done. The ability to use the rights as a consumer of media most frequently enough facilitators her. So as a whole it can be said that on this criterion that is a person's ability to communicate and build social relations through the media and be able to produce media content, the ability of the facilitator is also still limited.

Referring to the results of the three individual competency framework criteria, the discussion that can be raised is Peace Education in Women's Schools in Poso District indeed is a learning activity or non-formal education. Non formal education activities can take place in a variety of modes [13], and this is also carried out in women's schools. The creation and freedom of managing peace education in a non-formal context can also be done by utilizing social media that has mushroomed in the community. Because the aim of peace education is peace building which is carried out independently by the community and the creation of a culture of peace in the community. This goal can be realized, among others, if women, especially participants of peace school women in Poso District have the ability to digital media literacy.

But as Martin (2008) said (herlina, 2016) [7] that digital literacy is a multi-dimensional skill. One can master digital literacy gradually because one level is more complicated than the previous level. Even though the results of the digital literacy of the Women's School facilitators as a whole still need to be improved, but it is still in the category that is very reasonable because this skill is a new thing that must be possessed by humans in dealing with 
the current digital environment. Moreover, aspects of digital media are not only technically new but also quite different from conventional media or other print media, digital media presents a very interactive communication logic. This certainly makes users must have the ability not only technical but also understand the content, and active and interactive functions of producing messages. Because interactions on digital social media have consequences for personal safety, privacy, controlling excessive consumption and addressing differences. The ability of digital media literacy in matters relating to peace education, must pay close attention to this ability and the consequences mentioned earlier. Because the purpose of using social media and digital media is precisely to extend news of peace in the wider community.

However, the ability of women to socialize [14] both directly and by utilizing social media in this case Facebook becomes a major capital for peace building. Because on social media it is possible for women to carry out social interactions equally and can shape their cognitive, cultural and social developmental ways. Social media can be a place for sharing information and communication and allowing dialogue about value perspectives [15]. Women must be able to understand this benefit in using social media, so that the purpose of organizing women's schools to make women peace agents can be realized. Moreover, according to Helpiastuti [14] the appearance of women's identity in social media (in this case Facebook) as a whole is so complex. Indeed, in using facebook there are still motives among others to maintain a relationship, take the time, to join the virtual community, entertain, feel good, find friends express themselves and find information. But this movement can certainly be developed further through increasing digital literacy so that social media can be utilized to educate the public about peaceful life [16].

\section{CONCLUSIONS}

The ability of digital media literacy of the Women's School Facilitators in utilizing Facebook social media to develop peace education activities still needs to be increased again. The results of the study showed that the literacy ability of digital media facilitators of the Women's Schools by using the criteria in the Individual Competence Framework can be said for the first point of personal competence, namely technical skills are good. While the critical understanding point is still not enough or limited. Likewise for Communicative Abilities, the ability of facilitators is still limited. So it can be said that the digital literacy level of facilitators is at the first level, which is only at the Digital Competence stage. The ability to use social media to build peace needs to be enhanced. Peace education materials at the Women's School need to be added on how to use Facebook social media to expand and develop peace education activities

\section{REFERENCES}

[1] Yuliana Tacoh TB, "Model Pendidikan Perdamaian ' Ramah Perempuan' pada Sekolah Perempuan untuk Perdamaian,”. jurnalilmiahpaxhumana.org/index.php/issue/view/10/showToc2017

[2] W. Pertiwi, Facebook jadi medsos paling digemari di Indonesia. 2019. https://tekno.kompas.com/read/2019/02/05/11080097/facebook-jadimedsos-paling-digemari-di-indonesia.

[3] A. P. Damayanti, "Peran Media Sosial ' Facebook' Dalam Membentuk Solidaritas Kelompok Pada Aksi 411 DAN 212," vol. 7, no. 1, 2018.

[4] T. Carmichael and R. Norvang, "A Global Dialogue on Peace: Creating an 
International Learning Community Through Social Media,” Int. J. Teach. Learn. High. Educ., vol. 26, no. 3, pp. 445-452, 2014.

[5] M. Mulawarman and A. D. Nurfitri, "Perilaku Pengguna Media Sosial beserta Implikasinya Ditinjau dari Perspektif Psikologi Sosial Terapan,” Bul. Psikol., vol. 25, no. 1, pp. 36-44, 2017.

[6] N. Kurnia and S. I. Astuti, "Peta Gerakan Literasi Digital Di Indonesia: Studi Tentang Pelaku, Ragam Kegiatan, Kelompok Sasaran Dan Mitra Yang Dilakukan Oleh Japelidi," Informasi, vol. 47, no. 2, p. 149, 2017.

[7] Dyna Herlina S, "Membangun Karakter Bangsa melalui Literasi Digital, staffnew.uny.ac.id 2016

[8] B. G. Loka, "Kinerja Fasilitator Pembelajaran Luar Sekolah Di Kebun," Inerja Fasilitator Pembelajaran Luar Sekol. Di Kebun Raya Kebun Binatang Gembira Loka, pp. 686-696, 2018.

[9] M. Z. Muttaqin, "Kemampuan literasi media di kalangan Remaja rural di Kabupaten Lamongan," journal.unair.ac.id.,2015.

[10] M. Sulthan and S. B. Istiyanto, "Model Literasi Media Sosial Bagi Mahasiswa," J. ASPIKOM, vol. 3, no. 6, p. 1076, 2019.

[11] Kementrian Pendidikan and Kebudayaan . Jakarta, "MATERI PENDUKUNG," gln.kemendikbud.go.id. 2017.

[12] S. Giraldo Luque and O. Paredes, "Study Assessment Criteria for Media Literacy Levels Study Assessment Criteria for Media Literacy Levels Final Report Final Report edited by EAVI for the European Commission Prepared for the European Commission Information Society and Media Directorate-Gen," no. October, 2009.

[13] C. C. Carter, "Restorative practices as formal and informal education," J. Peace Educ., vol. 10, no. 1, pp. 36-50, 2013.

[14] Budi Selfi Helpiastuti, media sosial dan Perempuan (analisis wacana terhadap Facebook sebagai media komunikasi terkini bagi perempuan), repository.unej.ac.id, 2016

[15] Y. I. (2017). K. yang mengubah dunia. B. S. R. M. IDI Subandy Ibrahim, Komunikasi yang mengubah dunia. Bandung: Simbiosa Rekatama Media. 2017.

[16] R. Rahim, K. Saddhono, and D. Sulaksono. Unified modeling language as a design of interactive ebook application for android. Journal of Advanced Research in Dynamical and Control Systems. vol. issue. 5 pp. 634-637, 2019 